\title{
The role of interreligious dialogues on religious tolerance
}

\begin{tabular}{|c|c|}
\hline $\begin{array}{l}\text { Author: } \\
\text { Mahmood Va }\end{array}$ & $z i^{1,2}$ \\
\hline $\begin{array}{l}\text { Affiliations: } \\
{ }^{1} \text { Department } \\
\text { Hadith, Facult } \\
\text { and Islamic Sc } \\
\text { University of }\end{array}$ & $\begin{array}{l}\text { f Quran and } \\
\text { y of Theology } \\
\text { iences, } \\
\text { ehran, Iran }\end{array}$ \\
\hline $\begin{array}{l}\text { 2Department } \\
\text { of Religion an } \\
\text { Faculty of The } \\
\text { Religion, Univ } \\
\text { Pretoria, Sout }\end{array}$ & $\begin{array}{l}\text { f Science } \\
\text { Missiology, } \\
\text { ology and } \\
\text { ersity of } \\
\text { Africa }\end{array}$ \\
\hline $\begin{array}{l}\text { Research Proj } \\
\text { Project Leader } \\
\text { Project Numb }\end{array}$ & $\begin{array}{l}\text { ect Details: } \\
\text { : M. Sukdaven (1) } \\
\text { er: } 04616546\end{array}$ \\
\hline $\begin{array}{l}\text { Description: } \\
\text { Prof. Vaezi is } \\
\text { in the researc } \\
\text { 'Religion in Di } \\
\text { directed by Dr } \\
\text { Sukdaven, De } \\
\text { of Science of } \\
\text { Missiology, Fa } \\
\text { Theology and } \\
\text { University of }\end{array}$ & $\begin{array}{l}\text { articipating } \\
\text { ר project, } \\
\text { logue', } \\
\text { Maniraj } \\
\text { bartment } \\
\text { Religion and } \\
\text { culty of } \\
\text { Religion, } \\
\text { retoria. }\end{array}$ \\
\hline $\begin{array}{l}\text { Correspondin } \\
\text { Mahmood Vaє } \\
\text { mvaezi@ut.ac }\end{array}$ & $\begin{array}{l}\text { g author: } \\
\text { zzi, } \\
\text {.ir }\end{array}$ \\
\hline $\begin{array}{l}\text { Dates: } \\
\text { Received: } 08 \mathrm{~J} \\
\text { Accepted: } 23 \\
\text { Published: } 26\end{array}$ & $\begin{array}{l}\text { une } 2018 \\
\text { uly } 2018 \\
\text { Nov. } 2018\end{array}$ \\
\hline $\begin{array}{l}\text { How to cite th } \\
\text { Vaezi, M., } 201 \\
\text { of interreligio } \\
\text { on religious to } \\
\text { HTS Teologies } \\
\text { Theological St } \\
\text { a5146. https:/ } \\
10.4102 / \text { hts.v }\end{array}$ & $\begin{array}{l}\text { is article: } \\
8 \text {, 'The role } \\
\text { is dialogues } \\
\text { lerance', } \\
\text { Studies/ } \\
\text { udies } 74(3) \text {, } \\
\text { /doi.org/ } \\
74 \text { i3.5146 }\end{array}$ \\
\hline $\begin{array}{l}\text { Copyright: } \\
\text { (c) 2018. The A } \\
\text { Licensee: AOS } \\
\text { is licensed unc } \\
\text { Creative Comr } \\
\text { Attribution Lic }\end{array}$ & $\begin{array}{l}\text { IS. This work } \\
\text { Ifer the } \\
\text { nons } \\
\text { ense. }\end{array}$ \\
\hline Read online: & \\
\hline 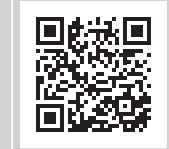 & $\begin{array}{l}\text { Scan this QR } \\
\text { code with your } \\
\text { smart phone or } \\
\text { mobile device } \\
\text { to read online. }\end{array}$ \\
\hline
\end{tabular}

Author:

Affiliations:

${ }^{1}$ Department of Quran and and Islamic Sciences,

${ }^{2}$ Department of Science of Religion and Missiology, Faculty of Theology and Religion, University of

Research Project Details: Project Leader: M. Sukdaven

Description:

directed by Dr Mani

Sukdaven, Department Science of Religion and Theology and Religion, University of Pretoria.

Corresponding autho : Mahmood Vaezi,

Dates:

Published: 26 Nov. 2018

How to cite this article: il, M., 2018, 'The role on religious tolerance', HTS Teologiese Studies/ a5146. https://doi.org/

Copyright: Licensee: AOSIS. This work is licensed under the Creative Commons Attribution License.

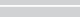
to read online.

\begin{abstract}
The application of the word 'dialogue' has a life as long as history and the old texts of religions are full of dialogues prevailing among different religious people. Reviewing and analysing the background and history of religious dialogue in the world, more than anything else, we understand the principle of necessity and position of dialogue as a common and public principle among religions, which in a broader view has been acceptable to most, if not all, religious people. This issue indicates that a spiritual and inherent sense is within the substantial core of all humans towards dialogue, which as a natural and inherent feature has been prevailing from the beginning of creation up to the present, and it will continue so. Firstly, employing the dialogue or saying and listening either to the inner self or the other people, when it is being formed with a commitment to human principles, will make human overpass a self-oriented attitude and recognition other persons. Secondly, it makes him/her listen and tolerate others' views. Thirdly, it makes him/her be committed towards the principle of tolerance and recognise of the other(s) as well. On this basis, the continuity of the principle of dialogue and emphasis on this innate tradition will cause the spread of the culture of tolerance, peace and tranquillity. Furthermore, distancing from dialogue will lay down grounds for a self-oriented attitude, prejudice, pride, omission of others and violence in human society. On this case, while giving originality to dialogue, Islam clearly and firmly puts dialogue forth as a basic principle in human relations and a base to achieve the common ideals of human communities, which are discussed in detail in this article.
\end{abstract}

\section{Introduction}

Peaceful coexistence, showing respect to others in one's social life, respecting the others' rights and using the potentialities and capacities of all people to seek social growth and perfection are among the goals that all heavenly books have emphasised and considered as the final goal under the titles of 'happiness', 'prosperity' and 'deliverance'.

The way to achieve this goal in human societies has been included in the programmes of divine religions, and all prophets have used dialogue to deliver ideas and findings to their audience. Speaking and listening are both essential components of peaceful social coexistence, but they are also effective and useful when based on reason and rationality, the principles and foundations of which are based on pure, natural human values equally shared among all human beings.

Not only talking but also listening to the words of others are signs of having tolerance. Practising the intellectual dialogue is a tool for increasing tolerance towards others. The importance of such a dialogue is most evident in confronting different followers of religions.

In this regard, human society needs more than ever to learn the culture of dialogue with the opposition and to disagree with others who are different in terms of views and behaviours. So the focal point of this research is to clarify the position of the principle of dialogue and to analyse the necessity of using such a common humanitarian approach to a peaceful coexistence of followers of religion and to emphasise its promotion in human affairs.

\section{Dialogue: Denotation and connotation}

The word dialogue means (ed. Eliade 1987:4, 343) 'simply conversation although in Western intellectual history its dominant meaning has been a piece of written work cast in the form of a conversation'. Al-hiwār الحوار [dialogue] in Arabic is a conversation that is face-to-face and comes to an end without any bias or prejudice. This word has three dimensions: colour, return and rotation (Ībn-e-Fāres 1983:2, 115). It seems that al-hiwār has been derived from hour حور, meaning return, and hiwōr refers to anything exchanged between the two individuals in a way that each 
one listens to the other's speech and responds to that. If one of these two does not respond to the other, there would be no conversation between them (Zubeidi 1414 AH:6, 317).

The word 'dialogue' can be considered another term for this concept. However, this term is more commonly associated with written meaning elements and literary applications (Cowie 1989), but the word 'dialogue' has been mentioned in many Persian translations. The word 'chat' also refers to this concept, but the most important meaning component of this word is being friendly and exchanging personal information (1989:131). The word 'discuss' means a type of conversation in which the aspects of the topic are deeply investigated and have a more serious and specified goal. 'Communication' is another related term incorporating any type of interaction between people with the aim of exchanging information (Zubeidi 1414 AH:6, 317).

Investigating different meanings and applications of this word indicates that speaking, the existence of at least two individuals and exchanging of ideas in a friendly environment are the main components of this word. It seems that one of the fundamental elements of the word 'dialogue' is the existence of two or more statements depending on the number of parties involved. These statements are made to express the accepted ideas and thoughts of the parties involved in a rational and effective exchange. It seems that the word 'dialogue' with all its beauty and spread cannot provide the fundamental components of this rational and effective exchange, because the exchange of ideas and thoughts does not necessarily revolve around speaking, but this exchange becomes effective only when speaking is accompanied by listening. In fact, the importance of listening to realise this salient goal is not less than that of speaking. It can be said that without listening, speaking does not enjoy a solid foundation. In other words, being concise and appropriate in speech are both the main pillars of the rational exchange of ideas and thoughts.

\section{John Hick's Copernican revolution}

Professor John Hick (1973) has tried to solve the plurality and conflicting views among the religions through his Copernican revolution, based on astronomy in which it:

involved a shift from the dogma that [the earth is the center of the revolving universe to the realization that it is the sun that is at the center, with all planets, including our earth moving around it. (p. 131)

He believes that we 'must involve an equally radical transformation of our conception of the universe of faiths and the place of our own religion within it' (1982:36), and:

a shift from the dogma that Christianity is at the center to the realization that it is God who is at the center, and that all the religions of mankind including our own, serve and revolve around Him. (1973:131)

Hick's suggestion is that all religions should stop paying attention to unimportant differences and details and consider faith in and worshipping their God as the true foundation of their religion. Therefore, in the era when the world has become a communication unit, the intrinsic element of religion becomes a basis for the unity and approximation of all religions, so that the foundation for a global theology is established. All religions should remain committed to their principles and develop their comparative theology according to their original experience of religion, but all these theological systems and comparative theologies should be organised on common ground.

Hick started his approach, which was to some extent the result of his discussions with Muslims, first among the Christians and removed traditionalism from the churches with temerity. As a consequence, the statement of the second Vatican Council accepted the mutual respect with the Muslims as one of its tenets (Gerald o' Collins 2013:25).

The Encyclopedia of Religion has introduced the following types of dialogue as common types in the previous decades:

1. Discursive dialogue, debate or discussion involves meeting, listening, and discussion on the level of mutual component intellectual inquiry.

2. Human (buberian) dialogue resets on the existential foundations.

3. Secular dialogue stresses that there are tasks to be performed in the world and believers in different creeds may share in a program of joint action, without any attention to their respective convictions.

4. Spiritual dialogue (ed. Eliade 1987:347), which takes an introspective approach without any attempt to debate and puts an emphasis on the superiority of intuition and experience over rational thinking.

Emphasising the different types of dialogue, Islam has discussed the basis of dialogue and has asserted that reason and rationality is the most important foundation of dialogue.

\section{Dialogue in the viewpoint of the Holy Qur'an}

The Holy Qur'an introduces (Fazlullāh 1417:55) dialogue as an innate characteristic of human beings and considers it in line with human nature. The holy book of Muslims (Q18:54) asserts that man has been created in a way to consistently encounter all sorts of issues, phenomena and ideas without being calmed. Therefore, it can be seen that humans' sense of curiosity, once aroused about something, is also aroused about its antithesis. It looks for both the right and the wrong to talk about them with others.

The words hiwár and jadal [dispute] have been widely used in the Holy Qur'an. hiwár has been used twice, in Kahf chapter, verses 34 and 37, and also once in Mojadeleh chapter, verse 1. The word jadal has been used 27 times in the book (e.g. Q11:32, 40:5, 4:107 and 22:8). For instance, God in Ankabūt chapter (verse:46) has warned Muslims not to argue with the People of the Scripture except in the way that is best. 
In addition, the Qur'an sometimes considers this as a natural trait of humans and, for example, asserts that humans are likely to argue about everything (Q18:52).

A cursory look into these verses indicates that the application of the word jadal is not limited and it can be used about general and specific issues and in various religious and social topics. It seems that the widespread application of this word in the Holy Qur'an reflects the confrontation of Islam with various issues and circumstances related to the internal and external aspects of society. Islam has faced all these challenges to pose a similar challenge to its opponents without attaching value to some thoughts and ideas and showing superiority. Accordingly, (Fazlullāh 1417) it believes that Islam proposed a kind of jadal that is based on direct dialogue challenging ideas and thoughts. Therefore, it can conquer the realm of thought by questioning ideas and providing rational answers for them, and by institutionalising the culture of research and inquiry in its followers (1417:4249; Taskhiri 2011). The purpose of all these for Islam is to improve individuals' self-awareness and generate ideas grounded upon certainty.

\section{Types of dialogues based on the audiences \\ A self-talk}

The structure of perception and understanding and the analysis and processing of findings in an individual is in a way that humans are the first audiences and, hence, humans spend a lot of time talking with themselves. In a religious sense, faith is the result of the process of talking with oneself. To put it differently, faith is not possible without any deep internal thoughts. It seems that all of Islam is a movement that starts with a dialogue with oneself. The dialogue-based movement of human thought deals with a number of possible issues or the evaluation of a theory in comparison with another one, upon which the personality and identity of one is dependent. The internal dialogue leads to the expression of feelings and emotions on the one hand and thoughts and ideas on the other hand. This movement is in a sphere of reason and feelings. This is a dialogue that builds humans' strong personalities and commitment.

As a matter of fact, a person who does not live with constant dialogue with himself should not take part in a dialogue with others.

In short, dialogue can lead humans to have satisfaction and self-reliance, so that they are not uncertain and hesitant in intellectual and emotional conflicts. Without dialogue, these conflicts will disturb individuals' mental peace and security.

\section{Dialogue with others}

As Islam puts emphasis on the natural movement of thought to reach faith, it is reasonable to attach importance to talking with other peoples who have different thoughts, because this guides the movement of thought through listening.
This assumption has been the basis of all prophets' dialogues with individuals and groups to invite them to worshipping God. Therefore, all people would enter into a discussion with them, causing a real debate between them. They would express their opinions and the prophets had the opportunity to amend their incorrect beliefs. Nevertheless, their reaction was not always positive. Examining the stories of prophets in the Holy Qur'an reveals that they often scolded and belittled the prophets, did not succumb to logic and reason and did not listen to the truth (Tantaiwi 1997:13). This shows that dialogue, criticism and correction are not new issues, and they began with the advent of religion.

\section{Tolerance in the Islamic culture}

One of the prevailing and highly applied concepts in Islam which has been emphasised by the Holy Qur'an, the holy prophets and infallible Imams' traditions is the so-called term tolerance, which has a direct connection and interaction with the principle of dialogue and is in one way or another the sweet fruit and natural result of the dialogue process.

In this precise discussion, firstly, we will deal with the semantic etymology and then will review it through the Quranic verses and traditions, and finally, we will analyse the effects and influences of these two principles on each other.

\section{Toleration in semantic and terminology}

Dehkhuda [a prominent Iranian linguist and author of Dehkhuda Dictionary] says: 'Tolerance means to treat affectionately, to deal with something softly, showing affection and tenderness'. He also puts forth a second meaning for toleration: 'to show tolerance, to compromise' (Dehkhuda, Mūdará I مدار Entry)

The triad root of this word is 'درى' Dari or 'درا" Darä (Ibn Färes 1983A.H. 2, 271) and means 'awareness and knowledge about something which is obtained indirectly, irregularly and through expedience'.

'درا' Dara originally meant 'repel' (RaghebIsfahani 2015 A.H,:168). On this basis, the term Müdará tolerance means 'kindness and soft treatment' (Ibn Manzūr 1984:14, 255; Toraihi 1996 A.H.:1, 137). If being derived from the root, 'دريت' 'درى', Dari is in agreement with its main meaning in 'الظبى', DaraitoThabi as if humans can put themselves into the trap of their affection by bearing the opponent, showing expedience and tender treatment.

And if it is derived from 'در', Darä it means that humans will repel the badness through their tender treatment (Ibn Manzūr, 1984). The word Müdará, tolerance, is associated with the word 'رفق Rifq, tenderness and moderation.

This word originally meant tenderness and is against toughness and violation (Ibn Färes 1983:A.H., 4, 58). In all its applications, it means leniency and relaxation. 
Zubeidi says: الرفق: اللطف و هو ضد العنف Alrîfq: Al-lūtfwa Howa Zed al 'Onfi.e.Riffq, which means a favour against force (Zubeidi 1414 A.H.:13, 167).

Rifiq friend is the soft-natured and conformable companion (al-Farahidi 1405:5, 149), and the human's elbow is called 'مرفق'Merfaq because, relying on it, humans feel comfort.

Often, moderation in performing a job will be followed by easiness in performance and will cause goodness and stability of an action, so that the word Riffq has been applied with a meaning of 'moderation', 'smooth performance' and 'strengthening the action' (Ṭoraihi 1996:5).

Thus, in the concept of Müdara, tolerance, especially when it is taken from the root Dara, in a way, the meanings of expedience, avoidance and caution are hidden in it. Thus, it is mostly employed on opponents and enemies, opposite to its equivalent term, i.e. $R \bar{\imath} f q$, which is mostly applied on pros and cons and most often on non-opponents. ${ }^{1}$

\section{The concept of 'tolerance' in the Islamic culture and liberalism}

As it was observed, the concept of tolerance ${ }^{2}$ in the Islamic teachings is a kind of rational, kind and well-intentioned behaviour with others and passing over the disputes and adversities in social life which indicates human weightiness ${ }^{3}$ and moderation in individual and social life.

This concept as an ethical virtue results from human nature, which in the scene of individual and social behaviours is in agreement with keeping to an individual's values and beliefs. It is in a sense an indication of tolerance and a great spirit to bear the opposing views, which has always been emphasised by Islam.

But the Western and latter equal term for the word Müdarà is 'tolerance', which in its historical course has been selected as a rational solution to remove the problems and disputes created in the political systems in modern Western countries and has been extended to the fields of disagreements on race, gender and social differences (identity tolerance) too (see Edward 1998:431).

It is clear that in the word 'tolerance', the base of epistemological relativism is reinforced alongside the principle of religious pluralism in liberalism, which is different from its Islamic concept. The Islamic tolerance does not cast doubt on the truth in any way and is not in conflict with the ideological certainty of an individual.

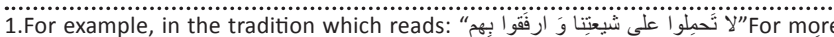

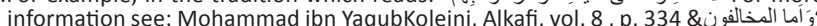
فيكلمُهُ بالكُدار اه" See: Mohammad BaqerMajlesi, Bahar al Anvar, vol. 75 , p. 401. Of course, this word is sometimes applied in a broad meaning and includes both groups such as: أمرنى ربى بمدار اه الناس, See: Mohamamd ibn YaqubKoleini, Alkafi, vol. 3, p. 179 .

2.Mūdarä and Refq

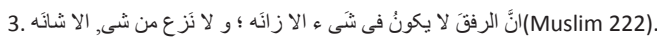

In other words, the concepts of true and false, correct and incorrect, value and anti-value, perfection and degradation and the like are not facing the Descartes didactic doubt or the Kantian organised doubt, but it is a jurisprudential and ethical principle taken from the Qur'an and life which is applied in different scenes such as: Legislation of religious laws (Majlesi1 1403:136, 7), freedom of idea and criticism (Q 3:71, 2:159 and also Sho'abaHaräini 1983:49), handling the opposing thinkers (Qaraḍawỉ 1977:30-32), treatment with religious minorities, and dealing with the opponents inside the Islamic society $(Q$ 60:8-9), including politics and governance.

Thus, the concept of Müdara in the Islamic culture is a very broad and general concept which has roots in the human essence of each individual and is considered as a virtue in the human community. In this article, the same term and meaning has been used.

\section{Tolerance in Quranic verses}

The Holy Qur'an as the last divine book which has been sent down to humanity (Q34:28) has spoken in different ways directly or indirectly about tolerance and moderation, for instance, to face the wrongdoers and weak people tolerantly, including to deal with the cultural weaknesses and society after the period of the prophet's mission tolerantly (Q3:153-155 and 5:71 and 6 and 7:32), to behave with the weak people in performing divine obligations tolerantly (Q3:25, 5:71 and 24:14-20 and 47:36-37), to deal with enemies of the truth and tyrants tolerantly (Q10:11 and 14:42-71 and 16:61 and 19:84) and also to show toleration in politics, law and Islamic culture, including dealing with the unwise in the prophets' life tolerantly (Q8:38 and 9:6 and 18:88 and 24:62), emphasis on tolerance in Islamic laws (Q2:280, and 18:65-82), edges of tolerance and compromise (Q11:12 and 20:94).

For instance, the Almighty God states: 'و قولوا للناس حسنا' i.e., speak fair to the people (Surah 2:83). In explaining this verse, Allameh Majlesi writes:

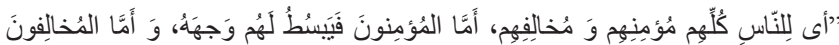

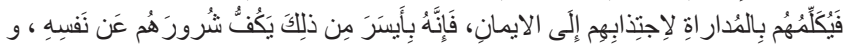

$$
\begin{aligned}
& \text { عَن إخو انِهِ المُؤمِنِينَ، لَّنَ }
\end{aligned}
$$

It refers to all people, including the believers and unbelievers. One should treat the believers pleasantly and talk to the infidels softly and tolerantly to attract them towards the faith and its least fruit, which would mean that one would immunise himself/herself and his/her faithful brothers against their harmful damages (Majlesi2 1505, 1:9, 5).

Describing the prophet's features, the Qur'an states:

$$
\text { 'فبما رحمة من الله لنتَ لهم ولو كنتَ فظًاً غليظ القلب لانفضّو ا من حولكه، }
$$

'It is part of the mercy of Allah that thou dost deal gently with them wert thou severe or harsh-hearted, they would have broken away from about thee' (Q3:159). 
In verse 4 of chapter Qalam, the description of the holy prophet of Islam reads, 'انكّ لعلي خلق عظيم': 'And surely thou hast sublime morals' (Q68:4). It goes without saying that one of the principles of educational and managerial psychology is good morality and to treat people tolerantly.

\section{The effects and results of compromise [رفقت]] and tolerance[مدارا] in Islamic traditions}

Concerning the effects and graces of compromise and tolerance, there are many traditions, and some of them are stated as follows:

\section{Safety of the religion and the world:}

Imam Ali (a.s.) stated:

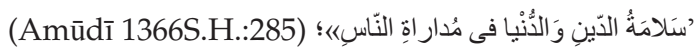

The health of religion and the world is promoted through dealing with people tolerantly. The health of the world is effected through tolerating people. However, the health of religion lies in keeping one's distance from evils and damages. This is not only favourable and ideal religiously but is an obligatory task. In the treatments opposite to tolerance, i.e. violation, there is a fear of damage and evils. Whenever humans treat people tolerantly, they will feel secure and therefore can perform their religious problems better than when feeling any distress from them.

\section{The establishment of sincerity and friendship}

Ali (a.s.) has considered sincerity and friendship as the

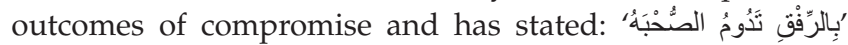
$(p, 186)$. It is through compromise and affection that friendship will become stable.

\section{Descending the grace into the life}

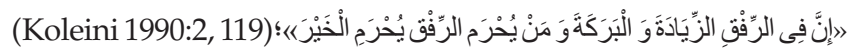

The prophet (pbuh) stated: There is abundance and grace in gentle treatment and whoever is deprived of softness will be deprived of the grace.

\section{Eradicating the revenge and enmity}

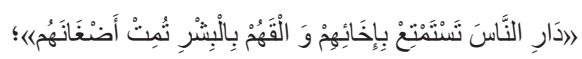

(Āmudi:465)

Treat the people tolerantly to utilise their brotherhood. Deal with the people in a pleasant manner to eradicate their revenges.

By this tradition, it means whenever you treat people tolerantly, they will establish brotherhood and friendship with you and you will enjoy it. Whenever you treat them in a good manner, their revenges will be removed and they will not pursue to bother you.

\section{Have the faults concealed}

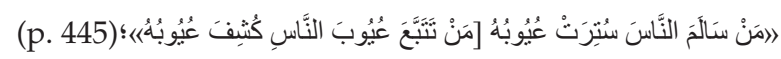

Whoever reconciles with people, all their faults will be concealed. By this it means to encourage humans to be in reconciliation with all people and have no conflict, and this causes their faults to be hidden. The one who holds such an attribute, the others will not bother him/her and will not try to divulge their faults, so that their faults and defects are hidden. Oppositely, one who quarrels with other people, the enemies pursue to find their faults and it is impossible not to reveal their faults and avoid being disgraced.

\section{Continuity of life}

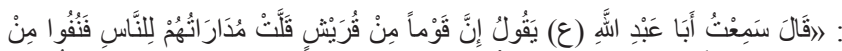

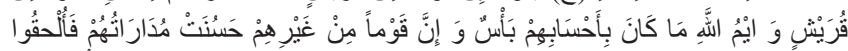

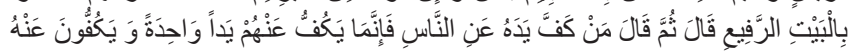

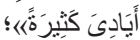

(Saduq 1983 AH:1, 17)

Imam Saduq (a.s.) stated, 'A group of Quraysh were disgraceful towards people and they were not treated tolerantly. The outcome was their expulsion from the Quraysh, while Oath to God, they had no defect from the family viewpoint. And there were other non-Quraysh group who used to treat people gently, and joined the lofty households'. Then he added, 'Whoever deprives people from his hand, he has deprived one hand from them but the people are deprived of many hands'.

Tolerance, half of the faith and the compromise, half of the life

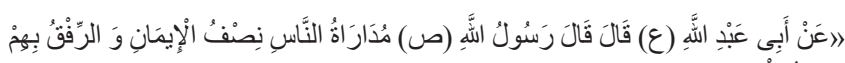

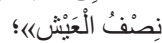

(Koleini 1990:2, 117)

Quoting from the prophet of Islam (p.b.u.h.), Imam Sảdeq (a.s.) stated, 'To treat the people tolerantly is half of the faith and to treat them gently is half of the life'.

\section{Keeping the faith}

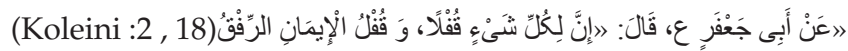

Imam Bagher (a.s.) stated, 'There is a lock for everything to protect it and the lock of faith is soft and gentle treatment. Pleasant manner and gentle treatment is protector of the faith because whoever loses softness and kindness and adopt violence and bad temper, he/she will forcibly do actions by which he/she will lose his/her faith'.

\section{Dialogue, the infrastructure of the principle of tolerance}

Compromise and tolerance in the Islamic society with their broad concepts including all individual and social scenes, and also the term 'Tolerance' with the mentioned meanings 
which were presented, are both in need of grounds to be fulfilled and stabilised, and without those grounds, neither of those two concepts could be materialised in a stable format.

The research shows that such a ground will be provided only by employing the principle of dialogue for the following reasons.

Firstly: The first step for sustainable social relations and providing a peaceful and sincere environment is to cross the platform of ego-centrism. Dialogue will cause humans to look past themselves and see the others and to put into effect the sense of need, exchange and interaction with them.

Secondly: Recognising the others' rights is known as the second step in the process of fulfilment of friendship and compromise in humanity and in Islamic communities. Dialogue with others will be fulfilled when keeping the rights of the others, when a person provides equal position and accepts to sit vis-à-vis the other individuals. This will be a suitable platform to establish a link and a sustainable tie.

Thirdly: Listening to the views of others in a dialogue is by itself a high step to respect the other side and to recognise the other's social and individual rights. The lofty words of Imam Ali (a.s.) on this subject-matter are noticeable when he states, 'Accustom your ear to listening exactly as you make your tongue accustomed to talking well' (Q39:18 \& Ghurar al ahekam 6234).

Fourthly: Dialogue in all fields and with any definition, when organised in a purposeful manner and continued, with no doubt, will provide a foundation for mutual intellectual synergy to promote the knowledge and vision of the society and promotion of behaviours.

The school of thought of Islam, with an emphasis on the principle of dialogue as a basic ground for tolerance and peaceful coexistence, emphasises a special type of dialogue, which the author terms 'the constructive and effective dialogue'. As a specific Islamic model, it is worth talking about the most important advantages of this type of dialogue.

Rationalism: A reason-oriented attitude: In line with stabilisation of tolerance and human warm relations in the public life of the society, Islam has put forth the noble rule of thought that indicates reason is a competent ruler and a scale for correctness or incorrectness of affairs as the base, to the extent that it has introduced the reason as the inner prophet of each human and the type of reason under consideration as the outer reason (Fazlullāh $1417 \mathrm{AH}: 61$ ), so that its role and position are in the peaceful social relations along with compromise and tolerance and also finding a way towards salvation and truthfulness (Koleini 1990:1, 20).

About one-fifth of the Quranic verses have been put forth with rational addresses and the necessity of contemplation and expedience. It also rebukes humans for a blind imitation (Asgari 2007:1, 15), lack of thought, vision and the like.

So, it places the base of dialogue on reason and insists on and emphasises this issue more than anything else.

Limitless status of dialogue subject-matters: In Islam, the scope of the subject-matters of dialogue is not limited. However, each subject, no matter how important it is, has an ability to be the subject of a dialogue. Even the existence of God, the personality of the divine prophets and the holy prophet (p.b.u.h.), and also in the denials and accusations of their deniers have been the subject matter of dialogues in the Holy Qur'an.

For example, whether or not the prophet was of an unsound mind or wise, magic or a true messenger, is his Qur'an a human or divine product? It states: (بقد نعلم انّهم يقولون انّما يعلّمد) بشر), 'we know indeed that they say: It is a man that teaches him' (Q16:103). (واذا قيل لهم ماذا انزل ربكم قالو ا اساطير الاولين (When it is said to them: What is it that your Lord had revealed? They say: Tales of the ancients!' (Q16:24).

Perhaps, one of the big challenges, which the Qur'an has tried to stand against, is this word by those who used to say, 'the Prophet is insane'. The Qur'an says to them:

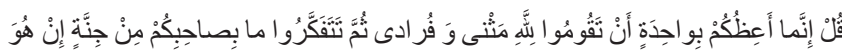

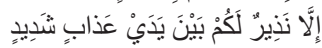

'Say, I admonish you on one point: that ye do standup before Allah (It may be) in pairs or (it may be) singly. And reflect (within yourselves), your companion is not possessed: he is no less than a warner to you in face of a terrible chastisement' (Q34:46).

It means that you must distance yourself this roaring, publicising atmosphere which separates humans from themselves. Return to yourself, because the group reason (when it is dominated) prevents humans from independent thought. Be dispersed in pairs, or singly, gaining distance from that ruling atmosphere, and contemplate about the actions and speeches of our messenger. You will soon understand that our prophet is not insane.

This point is considerable: that the Qur'an has omitted any kind of limitation on dialogue to keep stability in friendly relations and spread tolerance in society.

It had put forth some of the accusations to make them eternal and talk about them as it had been the subject-matter of the dialogue in the past. The basic ideological subjects related to faith and infidelities have not been exempted from this rule and have undergone discussion. The noble verses of chapter Ya-Sin (vv. 78 and 79) clearly confirm this claim:

And he makes comparisons for us and forgets his own origin and creation. He says: who can give life to dry bones and decomposed ones at that? Say: He will give them life who created them for the first time. For He fully knows all creation. (Tabatabaee 1996) 
The lack of limitation in the party of dialogue: As Islam does not accept any restriction in the subjects of the dialogue, it also does not accept any boundaries about the persons with whom we talk.

The primary rule and principle is that we can talk with any individual from whom we are intellectually, ideologically, politically and socially different, to supply the maximum rate of tolerance and social compromise. Just as God has talked with the demon in chapter A'raf, verse 11-18 (Tabrasi 1996). On the other hand, he has permitted the angels to talk about the creation of humans. The verse reads:

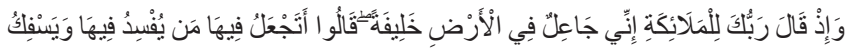

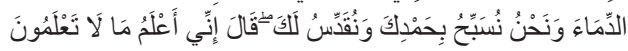

Behold, thy Lord said to the angels: I will create a vicegerent on earth. They said, Wilt thou place therein one who will make mischief therein and shed blood? Whilst we do celebrate thy praises and glorify thy holy name? He said, I know what ye know not? (Q2:30)

In this dialogue, the glorious God did not rebuke or punish them but responded, 'انى اعلم ما لا تعلمون', I know what ye know not. Thus, Islam does not consider the personality of anybody to be too high that he/she might not be addressed in a dialogue and does not let anybody say that since I am higher than them, I would not talk with them.

Knowing is the natural right of humans and access to knowledge through related channels to a level which does not allow any corruption will be free for everybody. Any question mark including the general or detailed ones should be pursued to be placed within a reason and then to have the doubt eradicated. On the other hand, those who possess a part of knowledge are dutiful to put it at the disposal of others and assist to achieve an assertive certainty. The Holy Qur'an has threatened those who hoard the knowledge and deny the divine evidences to its damnation (Q2:147), because they have kept back the people in the poverty of knowledge and epistemology. Fazlullāh emphasises that this issue will impose damage to the peaceful life of all walks of life (1417 AH:60).

The freedom of thought in the light of the law: The emphasis of Islam on dialogue in line with access to the truth is merely through a scientific path. So, it emphasises the freedom of the parties in a dialogue to put forth their opposing ideas. Even if the opposing view is disagreement with the public view, still no one has a right to object to or combat it with any abuse (Ṭantảwi 1997:31).

There is no room left for demagogy and the others have no right to accuse him/her of infidelity, misleading, straying, heterodoxy and excommunication or words like that. In confronting some of the enemies or unaware people, the holy messenger (p.b.u.h.) stated:

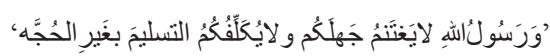

The Prophet of God does not profit by your ignorance and does not force you to surrender to him without any reason (Majlesi1 $1403 \mathrm{AH}: 9,313)$. Also, the review of the life of Imam Sadeq (a.s.) makes this reality much clearer.

An Imam used to sit near Ka'aba in al-Masjid al-Harām, [the sacred mosque] to talk with a group of heretics and doubtful people like Ibn al-Muqaffa' and ibn abi al-Ouja' on theological and philosophical issues. Sometimes, these dialogues were extended to the stage of irrational and ridiculous challenges.

At the same time, they were not leading to any violated behaviour. A person says an individual told him, 'How long do you want to turn round these rocks (Ka'aba)?' The Imam calmly and in a pleasant manner responded to his question through a discussion on philosophy, secrets of Hajj pilgrimage and its benefits (Koleini 1990:1, 77).

Thus, the constructive dialogue in the view of Islam is a dialogue, which relies on the base of freedom of thought in the arena of debate to supply the public interest.

Avoid egocentrism: Constructive dialogue in Islam to spread the culture of compromise and tolerance has another advantage which is noticeable in intellectual confrontations; humans should distance themselves from emphasising and insist on their own personal views, opposite to the method which gives originality to the personal own idea and accepts the correctness of the views of others doubtfully. Because the known method of dialogue in this world is that my views are correct and there is a possibility of error, but the views of others are wrong and there is a possibility that they might be correct.

The base of this rule is that the accuracy and correctness is mostly accumulated in our minds, while in the other hands error and incorrectness are basically far from us and are in the mind and view of the addressee. The Qur'an disagrees with this viewpoint and states:

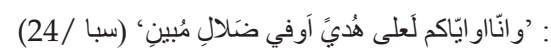

And it is certain that either we or ye are on right guidance or in manifest error (Q34:24). In fact, you or we are in a manifest misleading or error (see Figure 1).

The Holy Qur'an has attributed the attribution of orientation and misguidance to the parties of a dialogue from the viewpoint of denial or assertion. So, in the atmosphere of Islamic dialogue, there is no sensual aspect for the dynamism of ideas but merely the truth-seeking aspect far from any fear, complexity and hardness is concerned. One of the features of this method is that the one who talks is assured that he and/ or she has been separated from the presumptions which can play an effective role in accepting or rejecting the materials.

However, it is important that this doubt is a common issue for both parties, such that in any field, it could inspire 


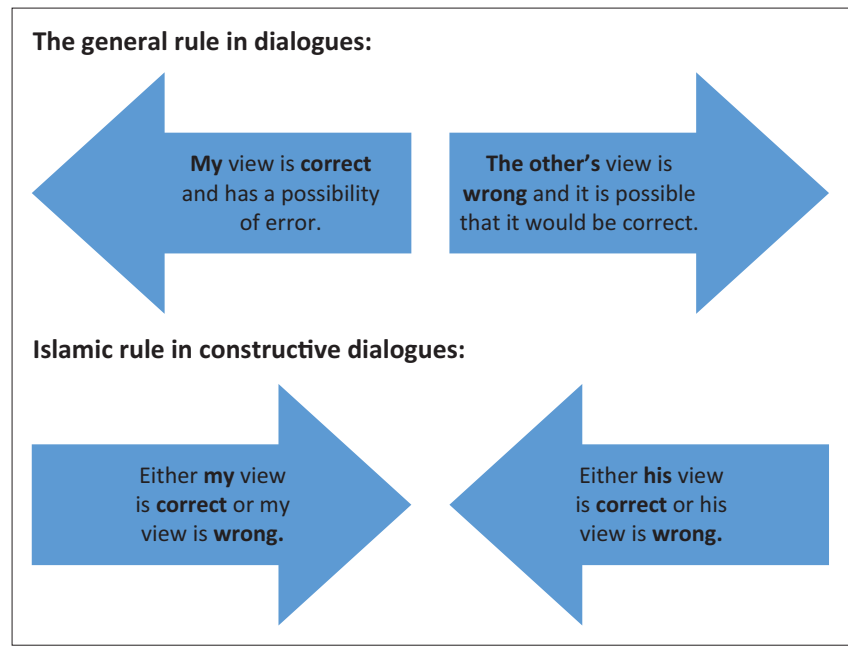

In the school of thought of Islam, human does not enter into a dialogue with a presumption of correctness of his own view, but his base is that it is possible that there is correctness or incorrectness in the views of each party.

FIGURE 1: Dialogues.

necessity of reconsideration of thought and without any prejudgment on correctness or incorrectness of viewpoints, to be only in pursuance of truth on the grounds of a dialogue which has been created based on awareness and intensive demand sense, no matter what would be the result.

Another aspect of this method, which emerges in confrontation with the opposing party, is that the acceptable thoughts will not become a barrier to accepting the materials of others. But it will create a foundation with humans to listen to, analyse and accept the ideas of the other. Sometimes, this new material corrects the human's incorrect beliefs to fulfil the Quranic orientation of 'هدى سبيلا', best guided on the way (Q17:84).

It seems that the value of this method is that it removes prejudice and dogmatism from human thoughts and does not allow new conflict to be opened between people. The prophet of Islam (p.b.u.h.) addresses the people in the Qur'an rhetoric: 'This is my book which is from God. If you have another book from God, present it, so that if it is true, we will obey it together' $(\mathrm{Q} 28: 49,50)$. Thus, the main issue is a truth-oriented and guidance-oriented attitude which should be identified and accepted wherever it is abruptly free from any kind of intellectual dogmatism or emotions (Fazlullāh 1417:86).

Now, in the atmosphere of the ignorant dreams of some of the advocates of religiosity and unfair violators, it is worthwhile for the followers of religions to make effort wholeheartedly in the direction of human values (Q39:18) and fulfilment of Safety, Peace and Compromise by resorting to the 'best words' and to bring about a world full of freedom, respect to the rights of the others, sincerity, affection and spirituality with tolerance creating a strategy towards the United Word (Q3:64).

\section{Acknowledgements Competing interests}

The author declare that he has no financial or personal relationship which may have inappropriately influenced him in writing this article.

\section{References}

Al-Farahidi, A.-K..A, 1405, Kitab al-'Ayn, rev. alMakhzumi, Mahdi \&al Samerae, Ibrahim DārolHijrah, Iran.

Amūdī, A., 1366S.H., Ghurar al-HikamWaDurar al-Kalim [Exalted Aphorisms And Pearls Of Speech], transl.Ridha Jaffer, Tahir, Ansariyan Publications, Qum, Iran.

Asgari, S.M., 2007, The role of the Imams in the revival of religion, MunirrCultural Publishing Center, Qum, Iran.

Cowie, A.P., 1989, Oxford advanced learner's dictionary, Oxford University Press, London.

Dehkhuda, A.A., Dehkhoda Dictionary, Wajja.com, viewed 20 February 2017, from http://vajje.com/en/search?query=\%D9\%85\%D8\%AF\%D8\%A7\%D8\%B1\%D8\%A7

Eliade, M. (ed.), 1987, The Encyclopedia of Religion, Macmillan Publishing Company, New York.

Edward, C. (ed.), 1998, Encyclopedia of philosophy, London.

Fazlullāh, S.M.H.., 1417, Al-hivārfel-Quran [Dialogue in the Quran], 5th edn., DarolMalak, Beirut.

Collins, G.O., 2013, The second Vatican council on other religions, Oxford University Press, London.

Hick, J., 1973, God and the universe of faiths, St.Martin's, New York.

Hick, J., 1982, God has many names, Westminster, Philadelphia.

Hume, R., 2008, World live religions, transl. A. Gavahi, A., 8th edn., Office for the Dissemination of Islamic Culture, Iran.

Ibn-e-Fares, A.-I.-F., 1983, Mo'ajamMaghayisūl-Loghah [Dictionary of comparative words], rev. AbdosallamMoḥammad, Haroon, Al-Aalamūl-Islamī, Qūm, Iran.

Ibn Kathir, D.I.-I.-'O., 1998, Tafsir-ūl-Quran Al'adim [Commentary of the holy Quran], rev. Mohammad HossienShamsūddin, Darol-KetbElmieh, Manshūrat Mohammad 'Ali Beiḍ̄nn, Beirut.

Ibn Manzūr, J.M., 1984, Lesan-ūl-'Arab ['Arabic Dictionary], AdabolHouzeh, Qūm, Iran.

Ibn Sho'abaHaràni, H.-I. A., 1983, Tūhafol-'Oghūl [Wisdoms' gifts], rev. Ghaffari Ali Akbar, Jam'ehMūdaresin, Qūm, Iran.

Koleini, M.Y., 1990, UsuleKafi [Sufficient Principles], transl. Mostafawi, Dar al Ketba al Eslamiyah, Tehran

Majlesi1, M.B., 1403 A.H., Bahar al-Anwar AljameaLedorarAkhbäreAema al Athar [A comprehensive book on traditions], 2th edn., Dar EhyaAltorath Al-Arabi, Beirut.

Majlesi2, M.B., 1405 A.H., Merat al-'Uqū [The mirror of intellects]. ed. H. Rasūli, Dar al-Kotob al-Eslamiyah, Tehran.

Muslim, Abulhossein Muslim ibn HajajGhosheiriNishabūri, 1425 A.H., Saḥị Muslim [The correct traditions], Dar Sader, Beirut.

Qaradawi, Y., 1977, Minorities, Al-qaradawi.com, viewed 10 January 2018, from https://www.al-qaradawi.net/node/5033

Ragheblsfahani, H.-I.-M., 2015, Mofradàt fi gharib al-Quran [Quranic dictionary], rev. Adnan, S., Nour, T., Nashr Ketab, Qum, Iran.

Tantȧwi, S.M., 1997, Adab al-Hiwár fi al-Islam [Moralities of Dialoguein Islam], al-Nahzah Publication, Egypt.

Tabrasi, F.-I.-H., 1996, Majmaul-Bayan fi Tafsir-ol-Quran [Interpretation of Quran] NaserKhosrow Publications, Tehran.

Ṭabatabaee, M.H., 1996, Al-mizan fi Tafsiral-Quran [Interpretation of Quran], Houzeh Publication Office, Qum, Iran.

Taskhiri, Sh. M. A., 2011, Al-hwárMaa-Zat wal-Akhar [Dialogue with himself \& the other one], The World Forum for Proximity of Islamic Schools of Thought Publications, Tehran.

The Holy Quran translated, viewed 15 February 2017, from Https://quran.com/2

Toraihi, F..-I.-M., 1996, Majmaul-Bahrain [Dictionary based on Quran \& Hadith], rev. H. Ashkiwari, Murtadavi Pub., Tehran.

Vaseti Zubeidi, Muheb al-Din Seyed Muhammad Mortaza, 1414 A.H., Taj al-Arus Min Jawaher al-Qamus [Arabic Dictionary]. rev \& edn. A. Shiri, Dar al Fekr, Beirut. 